\title{
Occurrence of Aspergillus section Flavi and aflatoxins in Brazilian rice: From field to market
}

Katsurayama, Aline M.; Martins, Ligia Manoel; lamanaka, Beatriz T.; Fungaro, Maria Helena P.; da Silva, Josué J; Frisvad, Jens Christian; Pitt, John I.; Taniwaki, Marta H.

Published in:

International Journal of Food Microbiology

Link to article, DOI:

10.1016/j.ijfoodmicro.2017.12.008

Publication date:

2018

Document Version

Peer reviewed version

Link back to DTU Orbit

Citation (APA):

Katsurayama, A. M., Martins, L. M., lamanaka, B. T., Fungaro, M. H. P., da Silva, J. J., Frisvad, J. C., Pitt, J. I., \& Taniwaki, M. H. (2018). Occurrence of Aspergillus section Flavi and aflatoxins in Brazilian rice: From field to market. International Journal of Food Microbiology, 266, 213-221.

https://doi.org/10.1016/j.ijfoodmicro.2017.12.008

\section{General rights}

Copyright and moral rights for the publications made accessible in the public portal are retained by the authors and/or other copyright owners and it is a condition of accessing publications that users recognise and abide by the legal requirements associated with these rights.

- Users may download and print one copy of any publication from the public portal for the purpose of private study or research.

- You may not further distribute the material or use it for any profit-making activity or commercial gain

- You may freely distribute the URL identifying the publication in the public portal 


\section{Occurrence of Aspergillus section Flavi and aflatoxins in Brazilian rice: from field to market}

Aline M. Katsurayama ${ }^{1}$, Ligia M. Martins ${ }^{1}$, Beatriz T. lamanaka ${ }^{1}$, Maria Helena P. Fungaro ${ }^{2}$, Josué J. Silva ${ }^{2}$, Jens C. Frisvad ${ }^{3}$, John I. Pitt ${ }^{4}$ \& Marta H. Taniwaki ${ }^{{ }^{*}}$

${ }^{1}$ Instituto de Tecnologia de Alimentos - ITAL

C.P. 139, CEP 13070-178, Campinas SP, Brazil.

${ }^{2}$ Universidade Estadual de Londrina

P.O. Box 6001, 6051-970 Londrina PR, Brazil.

${ }^{3}$ Department of Biotechnology and Biomedicine

Technical University of Denmark, Lyngby, Denmark.

${ }^{4} \mathrm{CSIRO}$ Agriculture and Food. P.O. Box 52, North Ryde, NSW 1670, Australia

${ }^{*}$ Corresponding author: Marta Hiromi Taniwaki. E-mail: marta@ital.sp.gov.br Address: Av. Brasil, 2880 - Campinas - SP - Cep 13070-178, Brazil.

Phone: (+55) 1937431819 


\section{Abstract}

The guarantee of the high quality of rice is of utmost importance because any toxic contaminant may affect consumer health, especially in countries such as Brazil where rice is part of the daily diet. A total of 187 rice samples, from field, processing and market from two different production systems, wetland from the state of Rio Grande do Sul, dryland, from the state of Maranhão and market samples from the state of São Paulo, were analyzed for fungi belonging to Aspergillus section Flavi and the presence of aflatoxins. Twenty-three soil samples from wetland and dryland were also analyzed. A total of 383 Aspergillus section Flavi strains were isolated from rice and soil samples. Using a polyphasic approach, with phenotypic (morphology and extrolite profiles) and molecular data (beta-tubulin gene sequences), five species were identified: $A$. flavus, $A$. caelatus, $A$. novoparasiticus, $A$. arachidicola and $A$. pseudocaelatus. This is the first report of these last three species from rice and rice plantation soil. Only seven (17\%) of the A. flavus isolates produced type B aflatoxins, but $95 \%$ produced kojic acid and $69 \%$ cyclopiazonic acid. Less than $14 \%$ of the rice samples were contaminated with aflatoxins, but two of the market samples were well above the maximum tolerable limit $(5 \mu \mathrm{g} / \mathrm{kg})$, established by the Brazilian National Health Surveillance Agency . 


\section{Introduction}

Rice is a major component of the diet in Brazil and many other parts of the world. Brazil is the world's ninth largest producer and the largest outside Asia (FAO, 2016), so rice quality and safety are of great importance. Two production systems exist in Brazil, the wetland system, prevalent in the South region, and the dryland system, prevalent in the Northeast region. In the wetland system, the rice is irrigated by controlled flooding. Two processes are in use in the dryland system: one that depends totally on rainfall and the other where supplementary irrigation decreases drought stress and provides higher grain quality.

The occurrence of species from Aspergillus section Flavi in the rice production chain is a concern due to the production of aflatoxins mainly by Aspergillus flavus, but perhaps by less common species also. Aflatoxin $B_{1}$ is classified by the International Agency of Research on Cancer (IARC, 1993) as a Group 1 carcinogen. Indeed aflatoxin $B_{1}$ is the most toxic known liver carcinogen.

Rice is an excellent substrate for fungal growth and mycotoxin production (Shotwell et al., 1966). Aspergillus section Flavi species and aflatoxins in rice have been studied in several countries including Brazil (; Almeida et al., 2012; Beber-Rodrigues and Scussel, 2013; Carvalho et al., 2010; Dors et al., 2011; Silva et al., 2008), South Korea (Ok et al., 2014; Park et al., 2005), India (Jayaraman and Kalyanasundaram, 2009; Reddy et al., 2009; Toteja et al, 2006), Uganda (Taligoola et al., 2011), Philippines (Sales and Yoshizawa, 2005), Nigeria (Makun et al., 2011) and Turkey (Aydin et al., 2011). Some studies have used inadequate fungal isolation methods, such as dilution plating or direct plating without surface disinfection, resulting only in data on the surface contamination of rice grains (Aydin et al., 2011; Fredlund et al., 2009). Many identifications of these species from rice have been based on identification by morphology and aflatoxin production (Beber-Rodrigues and Scussel, 2013; Carvalho et al., 2010; Park et al., 2005; Reddy et al., 2009), and have reported that $A$. flavus and $A$. parasiticus are the main species found in rice. A review of the 
occurrence of aflatoxigenic fungi and aflatoxins in rice from different parts of the world has been published elsewhere (Katsurayama and Taniwaki, 2017).

The aim of this study was to analyze the presence of aflatoxin producing fungi using modern methodology for isolation and polyphasic approaches for identification; to investigate the presence of aflatoxins in field, drying, storage, processing and market rice samples from the two different production systems mentioned previously, together with some market samples from São Paulo. Soil samples from wetland and dryland were also analyzed for the presence of aflatoxin producing fungi.

\section{Materials and methods}

\subsection{Samples}

A total of 187 rice samples each of approximately $1 \mathrm{~kg}$ were collected from wetland farms in Rio Grande do Sul (latitude 30ำ 51' 04" S, longitude 51ํ 48' 44" W) and dryland farms in Maranhão (latitude 05 $31^{\prime}$ '35" S, longitude 47을 $29^{\prime} 30^{\prime \prime} \mathrm{W}$ ), and during processing stages with paddy rice, husk, husked rice, bran, broken, brown, polished, parboiled and red rice. Included were samples from markets in these two regions along with São Paulo, because this state does not grow rice but consumption is high. Samples from São Paulo were of polished, brown, red, and parboiled rice, plus flake and, flour. Only two samples from the drying yard were collected in Maranhão because most of the rice is dried in mechanical dryers in processing plants. Table 1 shows the number of rice samples collected at each stage. Soil samples (approximately $1 \mathrm{~kg}$ ) were also collected from the rice plantation surface, 12 samples from Rio Grande do Sul and 11 from Maranhão. Rice and soil samples were enclosed in a plastic bags during transport from the collecting place to the laboratory, were all samples were refrigerated until analysed.

\subsection{Water activity of rice samples}


The water activity $\left(a_{w}\right)$ of all rice samples was determined in triplicate using an Aqualab Series 3TE instrument (Decagon, Pullman, WA, USA) at $25^{\circ} \mathrm{C} \pm 1$.

\subsection{Fungal isolation}

From each sample, approximately $100 \mathrm{~g}$ was taken randomly and surface disinfected with sodium hypochlorite solution $(0.4 \%)$ for $1 \mathrm{~min}$. Fifty grains were then distributed evenly in five Petri dishes containing Dichloran 18\% Glycerol Agar (DG18) and incubated at $25^{\circ} \mathrm{C}$ for 5 to $7 \mathrm{~d}$, according to Pitt and Hocking (2009). Non-particulate samples, i.e. bran, flour and soil, were analyzed by dilution plating. Samples $(25 \mathrm{~g})$ were diluted in peptone water $(0.1 \%, 225 \mathrm{~mL})$. Aliquots $(0.1 \mathrm{~mL})$ were inoculated onto DG18 plates and incubated at $25^{\circ} \mathrm{C}$ for 5 to $7 \mathrm{~d}$ (Pitt and Hocking, 2009).

\subsection{Fungal identification}

Isolates that had the appearance of belonging to Aspergillus section Flavi were transferred to Czapek Yeast Extract Agar (CYA; Pitt and Hocking, 2009) and incubated at 25 ${ }^{\circ} \mathrm{C}$ for $7 \mathrm{~d}$. Isolates were then examined on standard identification media for Aspergillus species: CYA, at $25^{\circ} \mathrm{C}$ and $37^{\circ} \mathrm{C}$, Malt Extract Agar (MEA) and Aspergillus flavus and parasiticus agar (AFPA), at $25^{\circ} \mathrm{C}$ (Pitt and Hocking, 2009). The incubation time for all media and conditions was $7 \mathrm{~d}$. Representatives of each species, initially distinguished by morphological and physiological characteristics, were further analysed by molecular methods and the production of extrolites.

\subsection{Molecular analysis}

Forty isolates from Aspergillus section Flavi, representing different groups according to morphological and physiological characteristics, were chosen. Genomic DNA was extracted using the Biopur mini spin genomic DNA extraction kit® (Biometrix, Curitiba, PR, Brazil) following the manufacturer's recommended protocol. For molecular phylogeny, part of the $\beta$ tubulin (BenA) gene sequence was determined as described in Taniwaki et al. (2012). The 
BenA sequences were aligned with those from type or neotype strains of all recognized species in Aspergillus section Flavi using Clustal W (Thompson et al., 1994). A maximumlikelihood tree was inferred using the Kimura-2-parameter model (Kimura, 1980) and to determine the support for each clade, a bootstrap analysis was performed with 1,000 replicates in the MEGA 7.0 software package (Kumar et al., 2016).

\subsection{Potential for aflatoxin production by Aspergillus section Flavi isolates}

Fungi identified as potential producers of aflatoxins $(n=383)$ were inoculated onto yeast extract sucrose agar (YES agar, Filtenborg et al., 1983) for $7 d$ at $25^{\circ} \mathrm{C}$ and then the agar plug technique (Filtenborg et al., 1983) was used to evaluate the capability of isolates to produce aflatoxins. Fungal extracts taken as plugs with a cork borer were placed on thin layer chromatography (TLC) plates, developed in a toluene: ethyl acetate: formic acid $90 \%$ : chloroform (7:5:2:5, v/v/v/v) mobile phase, and visualized under UV light at $365 \mathrm{~nm}$. A mixture of standard preparations of aflatoxins $B_{1}, B_{2}, G_{1}$ and $G_{2}$ (Sigma Aldrich, St. Louis, MO, USA) was used for comparison.

\subsection{Extrolite analyses}

Forty-seven representative isolates were analyzed for extrolite formation according to Frisvad and Thrane (1987) as modified by Houbraken et al. (2012). Isolates were grown on both CYA and YES agar for 7 and $14 \mathrm{~d}$ at $37^{\circ} \mathrm{C}$. Five plugs were taken from each medium and extracted with ethyl acetate/dichloromethane/methanol $(3: 2: 1)(\mathrm{v} / \mathrm{v} / \mathrm{v} ; 0.75 \mathrm{~mL})$ with formic acid (1\%; v/v) using 50 min ultrasonication. The solvents were evaporated and the dry extract re-dissolved in methanol $(0.4 \mathrm{~mL})$. After filtration, the extracts were analyzed using HPLC with diode array detection (Agilent series 1100 system with a Phenomenex Luna C18 column (Agilent, Santa Clara, CA, USA), according to Nielsen et al. (2011). Standards of the secondary metabolites were used to confirm identity. 


\subsection{Aflatoxin determination in raw rice}

Aflatoxin analyses were carried out on rice and rice products as follows, based on the method of Stroka et al. (2000).

\subsubsection{Clean-up}

Rice (approximately $200 \mathrm{~g}$ ) was finely ground using a laboratory mill (IKA A11 basic, Campinas, SP, Brazil), and passed through a sieve (18 mesh, $1.0 \mathrm{~mm})$. An aliquot $(25 \mathrm{~g})$ was extracted with methanol: water $(8: 2, \mathrm{v} / \mathrm{v} ; 100 \mathrm{~mL})$ with $\mathrm{NaCl}(2.5 \mathrm{~g})$ and homogenised in a shaker for $30 \mathrm{~min}$. The solution was first filtered using a quantitative filter (Nalgon, Itupeva, SP, Brazil) and a glass microfiber filter (VICAM, Milford, MA, USA). The filtrate (10 mL) was diluted in phosphate buffered saline (PBS, $60 \mathrm{~mL}$ ) and applied to an immunoaffinity column for aflatoxins (R-Biopharm Rhône Ltd, Darmstadt, Germany) at a flow rate of 2-3 $\mathrm{mL} / \mathrm{min}$. The column was then washed with distilled water $(30 \mathrm{~mL})$ and aflatoxins eluted with methanol $(1250 \mu \mathrm{L})$ and diluted with milli $\mathrm{Q}$ water $(1750 \mu \mathrm{L})$. This method was used for polished rice, paddy rice, rice flakes, black rice, brown rice and parboiled rice samples. For red rice, rice flour and bran rice samples, the PBS was replaced by PBS tween $(0.01 \%)$ and the elution was carried out with methanol $(2 \mathrm{~mL})$ and milli $\mathrm{Q}$ water $(1 \mathrm{~mL})$. For the red and brown rice mix and rice husks, methanol: water $(8: 2,150 \mathrm{~mL})$ was used for extraction, with PBS tween $(0.01 \%)$ instead of PBS, and eluted with methanol $(2 \mathrm{~mL})$, dried in a nitrogen flow and resuspended in methanol: water (2:3, v:v, $3 \mathrm{~mL})$.

\subsubsection{Chromatographic conditions}

The HPLC system used was an Agilent 1260 Infinity model system (Santa Clara, CA, USA) with a fluorescence detector set at $362 \mathrm{~nm}$ excitation and $455 \mathrm{~nm}$ emission for aflatoxins $G_{1}$ and $G_{2}$ and $425 \mathrm{~nm}$ emission for aflatoxins $B_{1}$ and $B_{2}$. An ODS (1.8 $\mu \mathrm{m}, 40 \times 15$ mm; Agilent, Santa Clara, CA, USA) guard column and a Zorbax Eclipse Plus C18 column (5 $\mu \mathrm{m}$, 4.6 x $150 \mathrm{~mm}$; Agilent, Santa Clara, CA, USA) were employed. The mobile phase was water:acetonitrile:methanol $(6: 2: 3, \mathrm{v} / \mathrm{v} / \mathrm{v})$, containing $\mathrm{KBr}(119 \mathrm{mg})$ and nitric acid $(4 \mathrm{M}, 350$ 
$\mu \mathrm{L} / \mathrm{L}$ ) at a flow rate of $1 \mathrm{~mL} / \mathrm{min}$ with injection volume of $20 \mu \mathrm{L}$. A post-column derivatization of aflatoxins $B_{1}$ and $G_{1}$ was performed with bromine using a KobraCell (R-Biopharm Rhône Ltd, Darmstadt, Germany).

Aflatoxin $B_{1}, B_{2}, G_{1}$ and $G_{2}$ standards (Sigma, St Louis, MO, USA) were used for quantification. The concentration of aflatoxins in the sample was determined by interpolation of the resulting peak area of each standard curve.

\subsubsection{Methodology optimization}

Detection and quantification limits were determined according to Eurachem Guides (Magnusson et al., 2015). To calculate the LOD, $s_{0}^{\prime}$ value was multiplied by 3 and for LOQ by 10. Spiked samples $(0.5 \mu \mathrm{g} / \mathrm{kg}$ of total aflatoxins $)$ in a polished rice sample free of aflatoxins was added. Eight parallel extractions were performed to calculate the recovery and the standard deviation.

The detection and quantification limit for aflatoxin $B_{1}, B_{2}, G_{1}$ and $G_{2}$ were $0.016,0.012$, 0.011 and $0.004 \mu \mathrm{g} / \mathrm{kg}$ and $0.054,0.039,0.038$ and $0.012 \mu \mathrm{g} / \mathrm{kg}$, respectively. The recovery percentage of total aflatoxins for polished rice at the level of $0.5,5$ and $25 \mu \mathrm{g} / \mathrm{kg}$ was $81.6 \%$, 88.5 and $95.8 \%$, respectively. The positive control analyses carried out in parallel for each rice sample had recovery values similar to those observed for polished rice. The Directives 98/53/EC of the European Union (Commission Directives, 1998) state that analytical methods for control of aflatoxins in food should provide recovery between 70 and $110 \%$ at levels between 1 and $10 \mu \mathrm{g} / \mathrm{kg}$ and 50 and $120 \%$ at levels $<1 \mu \mathrm{g} / \mathrm{kg}$.

The mean values of contamination were shown as lower bound (Lb), where the values below the limit of detection (LOD) were replaced by zero and upper bound (Ub) where the values were replaced by LOD divided by two.

\section{Results}

\subsection{Molecular identification}

A phylogenetic tree of Aspergillus section Flavi based on BenA is shown in Figure 1. This is constructed with sequences obtained in the present study and those retrieved from 
GenBank for each species type recognized in Aspergillus section Flavi (Samson et al., 2014). A. flavus was the predominant species $(n=34)$, in addition to this species these species from Aspergillus section Flavi were also found: A. novoparasiticus $(n=1), A$. arachidicola $(n=2)$, A. caelatus $(n=1)$ and A. pseudocaelatus $(n=2)$, which mostly confirmed the extrolite identification which helped identify the cultures as: $A$. flavus $(n=42)$, A. novoparasiticus $(n=1), A$. arachidicola $(n=1), A$. caelatus $(n=1)$ and $A$. pseudocaelatus $(n=2)$.

3.2 Incidence of Aspergillus section Flavi species and water activity of rice, rice products and soil

Infection of rice samples by species from Aspergillus section Flavi, and water activity of samples from different stages (fields, processing and markets) in wetland (RS), dryland (MA) and also São Paulo (SP) markets is shown in Table 1. As expected, field samples from wetland areas had an average $a_{w}$ of 0.932 , a maximum of $0.973 a_{w}$, and a minimum of 0.894 $a_{w}$, higher than dryland samples (average 0.825, maximum 0.953, minimum 0.770). At processing, water activity decreased from 0.818 and 0.799 , for paddy rice samples to 0.516 and 0.635 for polished rice samples in wetland and dryland, respectively. Samples from markets showed a range of 0.474 to 0.719 in different types of rice sold in the markets of the three regions.

Field samples from the wetland showed a higher rate of infection with Aspergillus section Flavi species (7/12 samples) than samples from dryland (1/12; Table 1$)$. The range of infection of individual grains was $24-100 \%$ and $0-2 \%$ from wetland and dryland samples, respectively. On the other hand, dryland soil showed a higher incidence of samples contaminated with Aspergillus section Flavi than wetland soil (Table 2). Infection in rice samples decreased during drying and processing stages in both regions, coinciding with a decrease in water content and also processing effects such as de-husking, polishing and/or parboiling. In the markets, some red and black rice samples showed higher infection than 
other samples (polished, brown and parboiled) coinciding with higher aw. Aspergillus section Flavi species were not found in rice flake and flour samples (Table 2).

\subsection{Potential production of aflatoxins and extrolite analyses}

Of the 383 isolates from Aspergillus section Flavi, 44 produced aflatoxins in culture: 39 producing B aflatoxins and five producing both B and G (Table 3). Aspergillus section Flavi species were common in wetland rice samples (182 isolates): none of these isolates produced aflatoxins, while only one isolate from soil produced $B$ and $G$ aflatoxins. From dryland samples, the isolate from field rice did not produce aflatoxins, but 34 of 47 isolates from soil did so, including three that produced both B and $G$ aflatoxins.

At processing, only one isolate from the dryland system produced aflatoxins. Five of 30 isolates from markets in São Paulo were positive for aflatoxin production; four producing only $B$ and one producing both $B$ and $G$ aflatoxins.

Table 4 shows the extrolites produced by the 48 isolates of Aspergillus section Flavi. Most $A$. flavus isolates did not produce aflatoxins, only seven (17\%) produced B aflatoxins, but $95 \%$ produced kojic acid and $69 \%$ cyclopiazonic acid as well. Other common metabolites found in $A$. flavus isolates were: aflavinines, flavimin, paspaline and paspalinine; three produced versicolorin and two 3-O-methysterigmatocystin. Isolates identified as $A$. arachidicola, A. novoparasiticus and A. pseudocaelatus produced aflatoxins B and G. All of them produced kojic acid and, except for A. pseudocaelatus, all produced cyclopiazonic acid as well. A. flavus AZ83-1783, isolated from a bran sample at the processing stage in the wetland, was unusual, as it produced only kojic acid.

\subsection{Aflatoxin analysis}

The levels of aflatoxins from field to processing and from markets are shown in Tables 5 and 6 , respectively.

The occurrence of total aflatoxins in samples was low as only 25 from 187 were positive (13.4\%). The average of total aflatoxin level found in wetland and dryland field 
samples was $0.35 \mu \mathrm{g} / \mathrm{kg}$ and $<\mathrm{LOD}(0.14 \mu \mathrm{g} / \mathrm{kg})$, respectively. At drying, the average of the two samples was $0.23 \mu \mathrm{g} / \mathrm{kg}$. In wetland and dryland processing samples the average was $0.04 \mu \mathrm{g} / \mathrm{kg}$ and $<0.14 \mu \mathrm{g} / \mathrm{kg}$, respectively. In the markets of wetland, dryland and São Paulo the following situation was found for the presence of total aflatoxins: 2 samples $(<L O D-0.28$ $\mu \mathrm{g} / \mathrm{kg}$ ), 6 samples (<LOD - $1.6 \mu \mathrm{g} / \mathrm{kg}$ ) and 9 samples (<LOD - $70.9 \mu \mathrm{g} / \mathrm{kg})$, respectively.

Two samples of red rice from São Paulo markets showed high concentrations of total aflatoxins, $70.9 \mu \mathrm{g} / \mathrm{kg}$ and $23.4 \mu \mathrm{g} / \mathrm{kg}$, well above the maximum permitted level of aflatoxins in cereals, $5 \mu \mathrm{g} / \mathrm{kg}$, established by resolution RDC $07 / 2011$ of the National Health Surveillance Agency (ANVISA, 2011). Most rice products were found to have no detectable aflatoxin levels including paddy rice, rice husks, husked rice, polished rice, brown, red and parboiled rice from wetland processing; brown rice, rice flour, red and flake rice from wetland markets, polished rice from wetland and São Paulo markets and parboiled rice from both dryland and São Paulo markets.

\section{Discussion}

In the present study, the wetland rice samples had a high infection with Aspergillus section Flavi species, while soil had only low levels, but aflatoxin concentrations in rice were low. According to Pitt et al. (2013), rice cultivated with an irrigation system in the first stages of development shows low levels of $A$. flavus in soil, with low infection in mature grains and in the final product, but if the grains are collected wet and then dried, the infection by $A$. flavus becomes more probable (Pitt et al., 2013). This was the case in the wetland region, where the production system used irrigation.

In the dryland production system, the seeds are cultivated when the rain becomes more regular, so the soil is not flooded as in the wetland system and fungi can develop. The dryland soil samples showed high contamination by Aspergillus section Flavi species, but the rice samples from the field had low infection rates and low levels of aflatoxins (below the limit of detection). As rice is not known to be infected with $A$. flavus before harvest (Pitt et al., 1994), these data indicate that rice from the wetland fields were harvested wet and then 
dried, while in the dryland field, the samples were drier when harvested. In South Korea, where the wetland system predominates, only one non-toxigenic $A$. flavus was found in 80 fresh harvest samples (Ok et al., 2014), but in India, where the dryland system predominates, the occurrence of $A$. flavus was reported in $83.5 \%$ of rice samples analyzed (Reddy et al., 2009).

Drying and storage are stages that require attention because if the drying is slow or the storage is poor, toxigenic fungi can develop and produce mycotoxins (Pitt et al., 2013). At processing, 7 of 13 samples of paddy rice from the wetland showed the presence of Aspergillus section Flavi species but none was an aflatoxin producer and only one sample had a low level of aflatoxins. These data therefore indicate that if drying and storage are carried out in a safe way, aflatoxin production is minimal.

The milling process decreases the level of aflatoxins in cereals, including rice. Sales and Yoshizawa (2005) observed a reduction of $78 \%$ of aflatoxins from brown rice to polished rice and a reduction of $38 \%$ of aflatoxins from milled rice to well milled rice. The milling process removes the bran from rice and in our study bran samples from both regions showed the presence of low levels of aflatoxins. In a study on aflatoxin reduction during shelling and milling, Trucksess et al. (2011) found that bran was the fraction with the highest contamination $(357 \mu \mathrm{g} / \mathrm{kg})$, followed by brown rice $(158 \mu \mathrm{g} / \mathrm{kg})$, paddy rice $(114 \mu \mathrm{g} / \mathrm{kg})$, polished rice $(56 \mu \mathrm{g} / \mathrm{kg}$ ) and husk (39 $\mu \mathrm{g} / \mathrm{kg})$. In our study, the presence of Aspergillus section Flavi species at the processing stage was low, and the samples with highest contamination were paddy rice, rice husk and rice bran.

Polished, brown and parboiled rice are the market types of rice most consumed in Brazil. Previous studies have shown low infection or absence of Aspergillus section Flavi species (Carvalho et al., 2010; Ok et al., 2014; Taligoola et al., 2011). In our study, red rice showed the highest contamination by Aspergillus section Flavi species and aflatoxins. This type of rice is not commonly consumed in Brazil. Aflatoxin contamination in polished rice in Brazil has been reported to be high, including $176 \mu \mathrm{g} / \mathrm{kg}$ in rice stored under inappropriate conditions (Almeida et al., 2012). Other reports show lower levels such as $2.04 \mu \mathrm{g} / \mathrm{kg}$ (Silva 
et al., 2008) and $1.2 \mu \mathrm{g} / \mathrm{kg}$ (Carvalho et al., 2010). Reports on brown rice have shown levels of $2.7 \mu \mathrm{g} / \mathrm{kg}$ (Ok et al., 2014) and parboiled rice high levels such as $30 \mu \mathrm{g} / \mathrm{kg}$ (Toteja et al., 2006) and $74 \mu \mathrm{g} / \mathrm{kg}$ (Dors et al., 2011). In the present study, polished, parboiled, brown, brown with red, flake, flour, and black rice had levels lower than $5 \mu \mathrm{g} / \mathrm{kg}$.

The presence of Aspergillus section Flavi species, especially $A$. flavus, has been reported in rice in several countries (Carvalho et al., 2010; Ok et al., 2014 Ok et al., 2014; Park et al., 2005; Reddy et al., 2009; Sales and Yoshizawa, 2005). After taxonomic revision of Aspergillus section Flavi using polyphasic approaches (Samson et al., 2014), a few strains previously identified as $A$. flavus or $A$. parasiticus, have been reclassified. In the present study, five species have been distinguished: $A$. flavus, $A$. caelatus, $A$. novoparasiticus, $A$. arachidicola and $A$. pseudocaelatus. This is the first report of these last three species from rice and rice plantation soil. $A$. novoparasiticus was first isolated in Brazil from clinical environments (Gonçalves et al., 2012), A. arachidicola from peanuts in Argentina (Pildain et al., 2008) and A. pseudocaelatus from Arachis burkartii leaf in Argentina (Varga et al., 2011). A. novoparasiticus, A. arachidicola and A. pseudocaelatus have also been found in maize kernels (Viaro et al., 2017), showing that with molecular data these species can be distinguished from other Aspergillus section Flavi species in foods.

In the present study, few isolates of $A$. flavus were able to produce aflatoxins in culture and most rice samples were not contaminated with aflatoxins. Using the agar plug technique, Carvalho et al. (2014) found that $26 \%$ of $A$. flavus isolates from Brazilian rice collected from markets produced aflatoxin $B_{1}$ and $B_{2}$ These results differ from many results with other crops where a higher proportion of $A$. flavus producing aflatoxins have been reported, including peanuts 50\% (Martins et al., 2017), brazil nuts 46\% (Calderari et al., 2013), and maize 70\% (Giorni et al., 2007). Although most of the A. flavus isolated in this study did not produce aflatoxins, $69 \%$ produced cyclopiazonic acid.

The present research has shown that species from Aspergillus section Flavi can occur in rice and in soils from rice plantations, from both wetland and dryland agricultural systems. However, most $A$. flavus strains encountered here did not produce aflatoxins and 
consequently the risk of aflatoxin production in rice was low at pre-harvest. However, if the rice is dried slowly or poorly stored, aflatoxin production may occur. In our study, red rice showed the highest contamination by Aspergillus section Flavi species and the highest aflatoxin levels. This type of rice is not commonly consumed in Brazil.

\section{Acknowledgements}

The authors acknowledge the financial support of "Fundação de Amparo a Pesquisa do Estado de São Paulo" (FAPESP) (Grant \# 2014/07498-7), "Conselho Nacional de Desenvolvimento Científico e Tecnológico" (CNPq) (Grant \# 305649/2014-0) and Fundação de Desenvolvimento de Pesquisa do Agronegócio. 


\section{References}

Almeida, M.I., Almeida, N.G., Carvalho, K.L., Gonçalves, G.A., Silva, C.N., Santos, E.A., Garcia, J.C., Vargas, E.A. 2012. Co-occurrence of aflatoxins $B_{1}, B_{2}, G_{1}$ and $G_{2}$, ochratoxin A, zearalenone, deoxynivalenol, and citreoviridin in rice in Brazil. Food Additives and Contaminants, Part A 29, 694-703.

ANVISA. Agência Nacional de Vigilância Sanitária. 2011. Resolução n 7, de 18 de fevereiro de 2011. (https://goo.gl/aYSdt4). Accessed on 04 ${ }^{\text {th }}$ August. 2017.

Aydin, A., Aksu, H., Gunsen, U. 2011. Mycotoxin levels and incidence of mould in Turkish rice. Environmental Monitoring and Assessment 178, 271-280.

Beber-Rodrigues, M., Scussel, V.M. 2013. Mycoflora and mycotoxicological quality of four freshly harvested paddy rice cultivars and relation with harvest to industry reception timing. Rice Science 20, 303-308.

Calderari, T.O., lamanaka, B.T., Frisvad, J.C., Pitt, J.I., Sartori, D., Pereira, J.L., Fungaro, M.H.P., Taniwaki, M.H. 2013. The biodiversity of Aspergillus section Flavi in brazil nuts: from rainforest to consumer. International Journal of Food Microbiology 160, $267-$ 272.

Carvalho, R.A., Batista, L.R., Prado, G., de Oliveira, B.R., Silva, D.M. 2010. Incidência de fungos toxigênicos e aflatoxinas em arroz. Ciência e Agrotecnologia 34, 946-952.

Commission Directive 1998/53/EC. 1998. Laying down the sampling methods and the methods of analysis for the official control of the levels of aflatoxins in foodstuffs. Official Journal of the European Communities.

Dors, G.C., Bierhals, V.da S., Badiale-Furlong, E. 2011. Parboiled rice: chemical composition and the occurrence of mycotoxins. Ciência e Tecnologia de Alimentos 31, 172-177.

FAO. (Food and Agriculture Organization of the United Nations). 2016. Food Outlook. Biannual Report On Global Food Markets. Rome: Food and Agriculture Organization. 
Filtenborg, O., Frisvad, J.C., Svendensen, J.A. 1983. Simple screening method for molds producing intracellular mycotoxins in pure cultures. Applied and Environmental Microbiology 45, 581-585.

Fredlund, E., Thim, A.M., Gidlund, A., Brostedt, S., Nyberg, M., Olsen, M. 2009. Moulds and mycotoxins in rice from the Swedish retail market. Food Additives and Contaminants 26, 527-533.

Frisvad J.C., Thrane U. 1987. Standardized high performance liquid chromatography of 182 mycotoxins and other fungal metabolites based on alkylphenone retention indices and UV-VIS spectra (diode array detection). Journal of Chromatography A 404, 195-214.

Giorni, P., Magan, N., Pietri, A., Berluzzi, T., Battilani, P. 2007. Studies on Aspergillus section Flavi isolated from maize in northern Italy. International Journal of Food Microbiology 113: 330-338.

Gonçalves, S.S., Stchigel, A.M., Cano, J.F., Godoy-Martinez, P.C., Colombo, A.L., Guarro, J. 2012. Aspergillus novoparasiticus: a new clinical species of the section Flavi. Medical Mycology 50, 152-160.

Houbraken J, Spierenburg H, Frisvad, J.C. 2012. Rasamsonia, a new genus comprising thermotolerant and thermophilic Talaromyces and Geosmithia species. Antonie van Leeuwenhoek 101, 403-421.

IARC (International Agency for Research on Cancer). 1993. IARC Monographs on the Evaluation of Carcinogenic Risks to Humans, Vol. 56. Some Naturally Occurring 12 Substances: Food Items and Constituents, Heterocyclic Aromatic Amines and Mycotoxins. IARC Press, Lyon.

Jayaraman, P., Kalyanasundaram, I. 2009. Natural occurrence of aflatoxins and toxigenic fungi in rice bran oil and de-oiled bran. Indian Journal of Science and Technology 10, 35-37.

Katsurayama, A.M., Taniwaki, M.H. 2017. Fungos e aflatoxinas no arroz: ocorrência e significado na saúde do consumidor. Brazilian Journal of Food Technology 20, e2017006, 1-12. 
Kimura, M. 1980. A simple method for estimating evolutionary rates of base substitutions through comparative studies of nucleotide sequences. Journal of Molecular Evolution 16, 111-120.

Kumar, S., Stecher, G., Tamura, K. 2016. Mega7: molecular evolutionary genetics analysis version 7.0 for bigger datasets. Molecular Biology and Evolution 33, 1870-1874.

Magnusson, B., Ellison, S.L.R., Örnemark, U. 2015. Eurachem Guide: Template for Eurachem Guides - A Guide for Guide Editors (1st ed.). Available from www.eurachem.org.

Makun, H.A., Dutton, M.F., Njobeh, P.B., Mwanza, M., Kabiru, A.Y. 2011. Natural multioccurrence of mycotoxins in rice from Niger State, Nigeria. Mycotoxin Research 27, 97-104.

Martins, L.M., Sant'Ana, A.S., Fungaro, M.H.P., Silva, J.J., Nascimento, M.S., Frisvad, J.C., Taniwaki, M.H. 2017. The biodiversity of Aspergillus section Flavi and aflatoxins in the Brazilian peanut production chain. Food Research International 94, 101-107.

Nielsen, K.F., Månsson, M., Rank, C., Frisvad, J.C., Larsen, T.O. 2011. Dereplication of microbial natural products by LC-DAD-TOFMS. Journal of Natural Products 74, 2338-2348.

Ok, H.E., Kim, D.M., Kim, D., Chung, S.H., Chung, M.S., Park, K.H., Chun, H.S. 2014. Mycobiota and natural occurrence of aflatoxin, deoxynivalenol, nivalenol and zearalenone in rice freshly harvested in South Korea. Food Control 37, 284-291.

Park, J.W., Choi, S.Y., Hwang, H.J., Kim, Y.B. 2005. Fungal mycoflora and mycotoxins in Korean polished rice destined for humans. International Journal of Food Microbiology 103, 305-314.

Pildain, M.B., Frisvad, J.C., Vaamonde, G., Cabral, D., Varga, J., Samson, R.A. 2008. Two new aflatoxin producing Aspergillus species from Argentinean peanuts. International Journal of Systematic and Evolutionary Microbiology 58, 725-735.

Pitt, J.I., Hocking, A.D., Bhudhasami, K., Miscamble, B.F., Wheeler, K.A., Tanbook-Ek, P. 1994. The normal mycoflora of commodities from Thailand. 2. Beans, rice, small 
grains and other commodities. International Journal of food Microbiology 23, 3553.

Pitt, J.I., Hocking, A.D. 2009. Fungi and Food Spoilage. Springer Science Business Media: New York.

Pitt, J.I., Taniwaki, M.H., Cole, M.B. 2013. Mycotoxin production in major crops as influenced by growing, harvesting, storage and processing, with emphasis on the achievement of Food Safety Objectives. Food Control 32, 205-215.

Reddy, K.R.N., Reddy, C.S., Muralidharan, K. 2009. Detection of Aspergillus spp. and aflatoxin $B_{1}$ in rice in India. Food Microbiology 26, 27-31.

Samson, R.A., Visagie, C.M., Houbraken, J., Hong, S.B., Hubka, V., Klaassen, C.H.W., Perrone, G., Seifert, K.A., Susca, A., Tanney, J.B., Varga, J., Kocsubé, S., Szigeti, G., Yaguchi, T., Frisvad, J.C. 2014. Phylogeny, identification and nomenclature of the genus Aspergillus. Studies in Mycology 78, 141-173.

Sales, A.C., Yoshizawa, T. 2005. Updated profile of aflatoxin and Aspergillus section Flavi contamination in rice and its byproducts from the Philippines. Food Additives and Contaminants 22, 429-436.

Silva, J.O., Cândido, L.M.B., Novello, D., Machado, C. 2008. Ocorrência de aflatoxinas em arroz consumido por militares do exército brasileiro por cromatografia em camada delgada e cromatografia líquida de alta eficiência. Ciência e Agrotecnologia 32, $1238-1244$.

Shotwell, O.L., Hesseltine, C.W., Stubblefield, R.D., Sorenson, W.G. 1966. Production of aflatoxin on rice. Applied Microbiology 14, 425-428.

Stroka, J., Anklam, E., Jorissen, U., Gilbert, J. 2000. Immunoaffinity column cleanup with liquid chromatography using post-column bromination for determination of aflatoxins in peanut butter, pistachio paste, fig paste and paprika powder: collaborative study. Journal of AOAC International 83, 320-340.

Taligoola, H.K., Ismail, M.A., Chebon, S.K. 2011. Mycobiota and aflatoxins associated with imported rice grains stored in Uganda. Czech Mycology 63, 93-107. 
Taniwaki, M.H., Pitt, J.I., lamanaka, B.T., Sartori, D., Copetti, M.V., Balajee, A., Fungaro, M.H.G., Frisvad, J.C. 2012. Aspergillus bertholletius sp. nov. from brazil nuts. PLOS ONE 7(8), 1-7 e42480.

Thompson J.D., Higgins D.G., Gibson, T.J. 1994. CLUSTAL W: improving the sensitivity of progressive multiple sequence alignment through sequence weighting, position-specific gap penalties and weight matrix choice. Nucleic Acids Research 22, 4673-4680.

Toteja, G.S., Mukherjee, A., Diwakar, S., Singh, P., Saxena, B.N., Sinha, K.K., Sarkar, S. 2006. Aflatoxin B1 contamination of parboiled rice samples collected from different states of India: a multi-centre study. Food Additives and Contaminants 23, 411-414.

Trucksess, M.W., Abbas, H.K., Weaver, C.M., Shier, W.T. 2011. Distribution of aflatoxins in shelling and milling fractions of naturally contaminated rice. Food Additives and Contaminants. Part A 28, 1076-1082.

Varga, J., Frisvad, J.C., Samson, R.A. 2011. Two new aflatoxin producing species, and an overview of Aspergillus section Flavi. Studies in Mycology 69, 57-80.

Viaro, H.P., Silva, J.J., Ferranti, L.S., Bordini, J.G., Massi, F.P., Fungaro, M.H.P. 2017. The first report of $A$. novoparasiticus, $A$. arachidicola and $A$. pseudocaelatus in Brazilian corn kernels. International Journal of Food Microbiology 243, 46-51. 


\section{Table Captions}

Table 1. Infection of rice samples by Aspergillus section Flavi,and water activity (aw) at different stages (fields, processing and markets) in three Brazilian regions: wetland (RS), dryland (MA) and markets of São Paulo.

Table 2. Colony Forming Units per gram (CFU/g) of Aspergillus section Flavi and water activity $\left(\mathrm{a}_{\mathrm{w}}\right)$ of rice products (bran, flake and flour) and rice soil samples from wetland (RS) and dryland (MA).

Table 3. Production of aflatoxins by Aspergillus section Flavi isolated from rice and soil samples from wetland (RS) and dryland (MA) and São Paulo.

Table 4. Extrolites produced by the Aspergillus section Flavi isolated from rice (Number of positive strains/Total number of tested strains).

Table 5. Incidence of aflatoxins $(\mu \mathrm{g} / \mathrm{kg})$ in rice samples from field to processing in wetland (MA) and dryland (RS).

Table 6. Incidence of aflatoxins $(\mu \mathrm{g} / \mathrm{kg})$ in rice from market samples in wetland $(\mathrm{RS})$, dryland (MA) and São Paulo (SP).

\section{Figure Caption}

Fig. 1. Maximum Likelihood tree based on BenA sequences data of Aspergillus section Flavi type strains and Aspergillus isolates from this study (in bold). Nodes supported by bootstrap values $\geq 70 \%$ are indicated by numeric values. 


\begin{tabular}{|l|}
\hline Processing \\
Market \\
a Soil \\
A Field \\
\hline
\end{tabular}

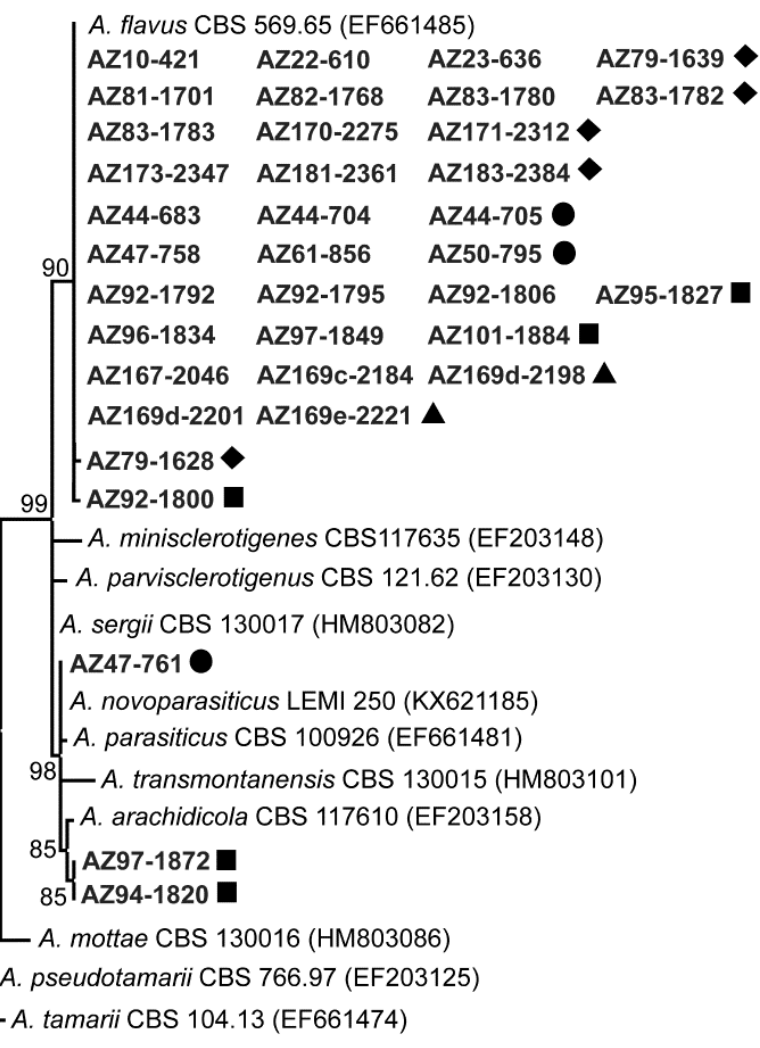

A. bertholletius ITAL 270/06 (JQ744022)

98 A. bombycis CBS 117187 (AY017547)

A. nomius CBS 260.88 (AF255067)

99 -A. pseudonomius CBS 119388 (EF661495)

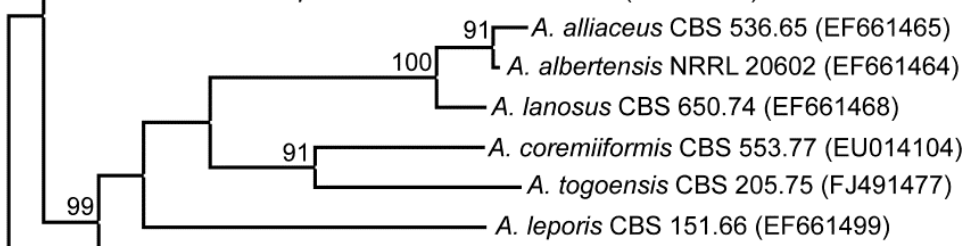

A. avenaceus CBS 109.46 (FJ491481) A. niger CBS 554.65 (EF661089)

Fig. 1 
Table 1. Infection of rice samples by Aspergillus section Flavi,and water activity (aw) at different stages (fields, processing and markets) in three Brazilian regions: wetland (RS), dryland (MA) and markets of São Paulo.

\begin{tabular}{|c|c|c|c|c|c|c|c|c|c|}
\hline \multirow{3}{*}{$\begin{array}{l}\text { Processing } \\
\text { stages }\end{array}$} & \multicolumn{9}{|c|}{ Regions } \\
\hline & \multicolumn{3}{|c|}{ Wetland (RS) } & \multicolumn{3}{|c|}{ Dryland (MA) } & \multicolumn{3}{|c|}{ São Paulo (SP) } \\
\hline & $\begin{array}{c}\text { № positive } \\
\text { samples/№ } \\
\text { samples }\end{array}$ & $\begin{array}{l}\text { Range of } \\
\text { infection } \\
(\%)\end{array}$ & $\begin{array}{l}\text { Mean aw } \\
\text { (range) }\end{array}$ & $\begin{array}{c}\text { № positive } \\
\text { samples/№ } \\
\text { samples }\end{array}$ & $\begin{array}{l}\text { Range of } \\
\text { infection } \\
(\%)\end{array}$ & $\begin{array}{c}\text { Mean aw } \\
\text { (range) }\end{array}$ & $\begin{array}{c}\text { № positive } \\
\text { samples/№ } \\
\text { samples }\end{array}$ & $\begin{array}{l}\text { Range of } \\
\text { infection } \\
(\%)\end{array}$ & $\begin{array}{c}\text { Mean aw } \\
\text { (range) }\end{array}$ \\
\hline Field & $7 / 12$ & $24-100$ & $0.932(0.894-0.973)$ & $1 / 12$ & $0-2$ & $0.825(0.770-0.953)$ & - & - & - \\
\hline Drying & - & - & - & $0 / 2$ & 0 & $0.708(0.596-0.821)$ & - & - & - \\
\hline \multicolumn{10}{|l|}{ Processing: } \\
\hline Paddy rice & $7 / 13$ & $0-38$ & $0.645(0.516-0.818)$ & $1 / 2$ & $0-22$ & $0.738(0.677-0.799)$ & - & - & - \\
\hline Husk & $3 / 4$ & $0-58$ & $0.600(0.562-0.646)$ & $1 / 1$ & $0-28$ & 0.740 & - & - & - \\
\hline Husked rice & $1 / 2$ & $0-2$ & $0.611(0.595-0.627)$ & $0 / 2$ & 0 & $0.685(0.680-0.690)$ & - & - & - \\
\hline Broken rice & - & - & & $0 / 4$ & 0 & $0.633(0.609-0.649)$ & - & - & - \\
\hline Brown rice & $1 / 4$ & $0-12$ & $0.590(0.575-0.599)$ & - & - & - & - & - & - \\
\hline Polished rice & $1 / 4$ & $0-2$ & $0.532(0.516-0.557)$ & $0 / 3$ & 0 & $0.639(0.635-0.647)$ & - & - & - \\
\hline Parboiled rice & $1 / 5$ & $0-2$ & $0.591(0.542-0.668)$ & - & - & - & - & - & - \\
\hline Red rice & $1 / 2$ & $0-2$ & $0.579(0.571-0.586)$ & - & - & - & - & - & - \\
\hline
\end{tabular}

\section{Markets:}




\begin{tabular}{|c|c|c|c|c|c|c|c|c|c|}
\hline Polished rice & $0 / 6$ & 0 & $0.565(0.544-0.582)$ & $1 / 19$ & $0-6$ & $0.591(0.509-0.673)$ & $0 / 10$ & 0 & $0.597(0.474-0.694)$ \\
\hline Brown rice & $0 / 12$ & 0 & $0.618(0.527-0.719)$ & $0 / 2$ & 0 & $0.592(0.526-0.658)$ & $2 / 19$ & $0-2$ & $0.581(0.530-0.624)$ \\
\hline Parboiled rice & $0 / 1$ & 0 & 0.593 & $0 / 6$ & 0 & $0.661(0.619-0.694)$ & $2 / 4$ & $0-4$ & $0.620(0.595-0.643)$ \\
\hline Red rice & $0 / 1$ & 0 & 0.621 & - & - & - & $3 / 10$ & $0-18$ & $0.607(0.544-0.678)$ \\
\hline Mix Brown+red & $0 / 3$ & 0 & $0.622(0.604-0.640)$ & - & - & - & $0 / 3$ & 0 & $0.584(0.560-0.598)$ \\
\hline Black rice & - & - & - & - & - & - & $4 / 8$ & $0-10$ & $0.632(0.580-0.696)$ \\
\hline
\end{tabular}


Table 2. Colony Forming Units per gram (CFU/g) of Aspergillus section Flavi and water activity (aw) of rice products (bran, flake and flour) and rice soil samples from wetland (RS) and dryland (MA).

\begin{tabular}{|c|c|c|c|c|c|c|}
\hline \multirow{3}{*}{ Stage } & \multicolumn{6}{|c|}{ Region } \\
\hline & \multicolumn{3}{|c|}{ Wetland (RS) } & \multicolumn{3}{|c|}{ Dryland (MA) } \\
\hline & $\begin{array}{c}\text { № positive } \\
\text { samples/№ samples }\end{array}$ & Range of CFU/g & Mean aw (range) & $\begin{array}{c}\text { № positive } \\
\text { samples/№ samples }\end{array}$ & Range of CFU/g & Mean aw (range) \\
\hline \multicolumn{7}{|c|}{ Processing: } \\
\hline Bran & $2 / 4$ & $<100-10^{3}$ & $0.609(0.465-0.749$ & $2 / 2$ & $<100-2 \times 10^{3}$ & $0.636(0.607-0.664)$ \\
\hline Flake & $0 / 1$ & $<100$ & 0.515 & $0 / 2$ & $<100$ & $0.612(0.602-0.621)$ \\
\hline Flour & $0 / 1$ & $<100$ & 0.503 & $0 / 1$ & $<100$ & 0.512 \\
\hline Rice soil & $3 / 12$ & $<100-2 \times 10^{3}$ & 1.00 & $9 / 11$ & $<100-2 \times 10^{3}$ & 1.00 \\
\hline
\end{tabular}


Table 3. Production of aflatoxins by Aspergillus section Flavi isolated from rice and soil samples from wetland (RS) and dryland (MA) and São Paulo.

\begin{tabular}{lccc}
\hline Stage & State (number of isolates) & AFB + & AFB $+\mathrm{G}$ \\
\hline Soil & Wetland (3) & 0 & 3 \\
& Dryland (47) & 34 & 0 \\
\hline Field & Wetland (182) & 0 & 0 \\
\hline Processing & Dryland (1) & 0 & 0 \\
\hline Detland (70) & 0 & 0 \\
\hline Markets & Dryland (45) & 1 & 0 \\
& SP (32) & 0 & 1 \\
\hline
\end{tabular}


Table 4. Extrolites produced by the Aspergillus section Flavi isolated from rice (Number of positive strains/Total number of tested strains).

\begin{tabular}{|c|c|c|c|c|c|}
\hline Extrolites & $\begin{array}{l}\text { Aspergillus } \\
\text { flavus }\end{array}$ & A. arachidicola & A. novoparasiticus & A. pseudocaelatus & A. caelatus \\
\hline Aflatoxin type B & $7 / 42$ & $1 / 1$ & $1 / 1$ & $2 / 2$ & $0 / 1$ \\
\hline Aflatoxin type $\mathrm{G}$ & $0 / 42$ & $1 / 1$ & $1 / 1$ & $2 / 2$ & $0 / 1$ \\
\hline Aflatrem & $6 / 42$ & $0 / 1$ & $0 / 1$ & $0 / 2$ & $0 / 1$ \\
\hline Aflavazol & $6 / 42$ & $0 / 1$ & $0 / 1$ & $0 / 2$ & $0 / 1$ \\
\hline Aflavinines & $18 / 42$ & $1 / 1$ & $0 / 1$ & $1 / 2$ & $0 / 1$ \\
\hline Asperfuran & $1 / 42$ & $0 / 1$ & $0 / 1$ & $0 / 2$ & $0 / 1$ \\
\hline Chrysogine & 0/42 & $1 / 1$ & $0 / 1$ & $0 / 2$ & $0 / 1$ \\
\hline Cyclopiazonic acid & $29 / 42$ & $1 / 1$ & $1 / 1$ & $0 / 2$ & $0 / 1$ \\
\hline Flavimin & $12 / 42$ & $0 / 1$ & $0 / 1$ & $0 / 2$ & $0 / 1$ \\
\hline Kojic acid & $40 / 42$ & $1 / 1$ & $1 / 1$ & $2 / 2$ & $1 / 1$ \\
\hline Miyakamide & $0 / 42$ & $0 / 1$ & $0 / 1$ & $1 / 2$ & $0 / 1$ \\
\hline Parasiticolide & $0 / 42$ & 0/1 & $0 / 1$ & $1 / 2$ & $0 / 1$ \\
\hline Paspaline & $14 / 42$ & $1 / 1$ & $0 / 1$ & $1 / 2$ & $0 / 1$ \\
\hline Paspalinine & $10 / 42$ & $1 / 1$ & $0 / 1$ & $1 / 2$ & $0 / 1$ \\
\hline Pseurotin & 0/42 & $0 / 1$ & $0 / 1$ & $0 / 2$ & $0 / 1$ \\
\hline Tenuazonic acid & $0 / 42$ & $0 / 1$ & $0 / 1$ & $0 / 2$ & $1 / 1$ \\
\hline Versicolorin & $3 / 42$ & $1 / 1$ & $0 / 1$ & $2 / 2$ & $0 / 1$ \\
\hline 3-O-methylsterigmatocystin & $2 / 42$ & $0 / 1$ & $0 / 1$ & $0 / 2$ & $0 / 1$ \\
\hline
\end{tabular}


Table 5. Incidence of aflatoxins $(\mu \mathrm{g} / \mathrm{kg})$ in rice samples from field to processing in wetland (MA) and dryland (RS).

\begin{tabular}{|c|c|c|c|c|c|c|c|c|c|c|}
\hline \multirow{2}{*}{$\begin{array}{l}\text { State } \\
\text { Stage (number of samples) }\end{array}$} & \multicolumn{5}{|c|}{ Wetland } & \multicolumn{5}{|c|}{ Dryland } \\
\hline & \multicolumn{5}{|c|}{ Field (12) } & \multicolumn{5}{|c|}{ Field (12) } \\
\hline & Aflatoxin $B_{1}$ & Aflatoxin $B_{2}$ & Aflatoxin $\mathrm{G}_{1}$ & Aflatoxin $\mathrm{G}_{2}$ & Total aflatoxins & Aflatoxin $B_{1}$ & Aflatoxin B & Aflatoxin $\mathrm{G}_{1}$ & Aflatoxin $\mathrm{G}_{2}$ & Total aflatoxins \\
\hline mean (Lb) & 0.337 & 0.011 & $<L O D$ & $<L O D$ & 0.349 & $<L O D$ & & $<L O D$ & $<L O D$ & $<L O D$ \\
\hline mean (Ub) & 0.343 & 0.016 & 0.006 & 0.002 & 0.374 & 0.008 & 0.006 & 0.006 & 0.002 & 0.02 \\
\hline Median & $<L O D$ & $<L O D$ & $<L O D$ & $<L O D$ & $<L O D$ & & $<L O D$ & $<L O D$ & $<L O D$ & $<L O D$ \\
\hline Range & $<\mathrm{LOD}-2.826$ & $<$ LOD - 0.085 & $<L O D$ & $<L O D$ & $<\mathrm{LOD}-2.95$ & $<L O D$ & $<L O D$ & $<L O D$ & $<L O D$ & $<L O D$ \\
\hline No of positive samples & $3(25 \%)$ & $2(16.7 \%)$ & 0 & 0 & $3(25 \%)$ & 0 & 0 & 0 & 0 & 0 \\
\hline \multirow[t]{2}{*}{ Stage (number of samples) } & & & & & & \multicolumn{5}{|c|}{ Drying (2) } \\
\hline & & & & & & Aflatoxin $B_{1}$ & Aflatoxin $B_{2}$ & Aflatoxin $\mathrm{G}_{1}$ & Aflatoxin $\mathrm{G}_{2}$ & Total aflatoxins \\
\hline mean (Lb) & & & & & & 0.224 & $\angle L O D$ & $<L O D$ & $<L O D$ & 0.225 \\
\hline mean (Ub) & & & & & & 0.228 & 0.006 & 0.006 & 0.002 & 0.235 \\
\hline Median & & & & & & 0.224 & $<L O D$ & $<L O D$ & $<L O D$ & 0.225 \\
\hline Range & & & & & & $<$ LOD - 0.448 & $\angle L O D$ & $<L O D$ & $<L O D$ & $<L O D-0.45$ \\
\hline No of positive samples & & & & & & $1(50 \%)$ & 0 & 0 & 0 & $1(50 \%)$ \\
\hline \multirow[t]{2}{*}{ Stage (number of samples) } & \multicolumn{5}{|c|}{ Processing - Paddy Rice (13) } & \multicolumn{5}{|c|}{ Processing - Paddy Rice (2) } \\
\hline & Aflatoxin $\mathrm{B}_{1}$ & Aflatoxin $B_{2}$ & Aflatoxin $\mathrm{G}_{1}$ & Aflatoxin $\mathrm{G}_{2}$ & Total aflatoxins & Aflatoxin $B_{1}$ & Aflatoxin $B_{2}$ & Aflatoxin $\mathrm{G}_{1}$ & Aflatoxin $\mathrm{G}_{2}$ & Total aflatoxins \\
\hline mean (Lb) & 0.042 & $<L O D$ & $<L O D$ & $<L O D$ & 0.046 & $<L O D$ & $\angle L O D$ & $<L O D$ & $<L O D$ & $<L O D$ \\
\hline mean (Ub) & 0.050 & 0.006 & 0.006 & 0.002 & 0.065 & 0.008 & 0.006 & 0.006 & 0.002 & 0.02 \\
\hline Median & $<L O D$ & $<L O D$ & $<L O D$ & $<L O D$ & $<L O D$ & $<L O D$ & $<L O D$ & $<L O D$ & $<L O D$ & $<L O D$ \\
\hline
\end{tabular}




\begin{tabular}{|c|c|c|c|c|c|c|c|c|c|c|}
\hline Range & $<$ LOD - 0.551 & $<L O D$ & $<L O D$ & $<L O D$ & $<$ LOD -0.60 & $<L O D$ & $<L O D$ & $<L O D$ & $<L O D$ & $<L O D$ \\
\hline No of positive samples & 1 (7.69\%) & 0 & 0 & 0 & 1 (7.69\%) & 0 & 0 & 0 & 0 & 0 \\
\hline \multirow[t]{2}{*}{ Stage (number of samples) } & \multicolumn{5}{|c|}{ Processing - Bran (4) } & \multicolumn{5}{|c|}{ Processing - Bran (2) } \\
\hline & Aflatoxin $B_{1}$ & Aflatoxin $B_{2}$ & Aflatoxin $\mathrm{G}_{1}$ & Aflatoxin $\mathrm{G}_{2}$ & Total aflatoxins & Aflatoxin $B_{1}$ & Aflatoxin $B_{2}$ & Aflatoxin $\mathrm{G}_{1}$ & Aflatoxin $\mathrm{G}_{2}$ & Total aflatoxins \\
\hline mean (Lb) & 0.164 & 0.012 & $<L O D$ & $<L O D$ & 0.175 & 0.167 & $<L O D$ & 0.007 & $<L O D$ & 0.175 \\
\hline mean (Ub) & 0.17 & 0.122 & 0.006 & 0.002 & 0.19 & 0.167 & 0.006 & 0.007 & 0.002 & 0.175 \\
\hline Median & $<L O D$ & $<L O D$ & $<L O D$ & $<L O D$ & $<L O D$ & 0.167 & $<\mathrm{LC}$ & 0.007 & $<L O D$ & 0.175 \\
\hline Range & $<L O D-0.656$ & $<L O D-0.047$ & $<L O D$ & $<L O D$ & $<$ LOD - 0.70 & $0.101-0.232$ & $<$ LOD & $<$ LOD - 0.014 & $<L O D$ & $0.10-0.25$ \\
\hline No of positive samples & $1(25 \%)$ & $1(25 \%)$ & 0 & 0 & $1(25 \%)$ & $2(100 \%)$ & 0 & $1(50 \%)$ & 0 & $2(100 \%)$ \\
\hline \multirow[t]{2}{*}{ Stage (number of samples) } & & & & & & \multicolumn{5}{|c|}{ Processing - Broken rice (4) } \\
\hline & & & & & & Aflatoxin $B_{1}$ & Aflatoxin $B_{2}$ & Aflatoxin $\mathrm{G}_{1}$ & Aflatoxin $\mathrm{G}_{2}$ & Total aflatoxins \\
\hline mean (Lb) & & & & & & 0.084 & $<$ LOD & $<L O D$ & $<L O D$ & 0.084 \\
\hline mean (Ub) & & & & & & 0.088 & 0.006 & 0.006 & 0.002 & 0.094 \\
\hline Median & & & & & & 0.121 & $<L O D$ & $<L O D$ & $<L O D$ & 0.12 \\
\hline Range & & & & & & $<$ LOD -0.23 & $<L O D$ & $<L O D$ & $<L O D$ & $<\mathrm{LOD}-0.23$ \\
\hline No of positive samples & & & & & & $2(50 \%)$ & 0 & 0 & 0 & $2(50 \%)$ \\
\hline
\end{tabular}

LOD: Limit of detection 
Table 6. Incidence of aflatoxins ( $\mu \mathrm{g} / \mathrm{kg}$ ) in rice from market samples in wetland (RS), dryland (MA) and São Paulo (SP).

\begin{tabular}{|c|c|c|c|c|c|c|c|c|c|c|c|c|c|c|c|}
\hline \multirow{3}{*}{$\begin{array}{l}\text { State } \\
\text { Type of rice (number of samples) }\end{array}$} & \multicolumn{5}{|c|}{ Wetland } & \multicolumn{5}{|c|}{ Dryland } & \multicolumn{5}{|c|}{ SP } \\
\hline & \multicolumn{5}{|c|}{ Polished (6) } & \multicolumn{5}{|c|}{ Polished (19) } & \multicolumn{5}{|c|}{ Polished (10) } \\
\hline & $\mathrm{AFB}_{1}$ & $\mathrm{AFB}_{2}$ & $\mathrm{AFG}_{1}$ & $\mathrm{AFG}_{2}$ & AFT & $\mathrm{AFB}_{1}$ & $\mathrm{AFB}_{2}$ & $\mathrm{AFG}_{1}$ & $\mathrm{AFG}_{2}$ & AFT & $\mathrm{AFB}_{1}$ & $\mathrm{AFB}_{2}$ & $\mathrm{AFG}_{1}$ & $\mathrm{AFG}_{2}$ & AFT \\
\hline mean (Lb) & $<L O D$ & $<L O D$ & $<\angle O D$ & $<L O D$ & $<L O D$ & 0.136 & 0.007 & $<L O D$ & $<L O D$ & 0.143 & $<L O D$ & $<L O D$ & $<L O D$ & $<\angle O D$ & $<L O D$ \\
\hline mean $(U b)$ & 0.008 & 0.006 & 0.006 & 0.002 & 0.02 & 0.142 & 0.012 & 0.006 & 0.002 & 0.157 & 0.008 & 0.006 & 0.006 & 0.002 & 0.02 \\
\hline Median & $<L O D$ & $<L O D$ & $<\angle O D$ & $<L O D$ & $<L O D$ & $<L O D$ & $<L O D$ & $<L O D$ & $<L O D$ & $<L O D$ & $<L O D$ & $<L O D$ & $<L O D$ & $<L O D$ & $<L O D$ \\
\hline Range & $<L O D$ & $<L O D$ & $<\angle O D$ & $<\angle O D$ & $<L O D$ & $<$ LOD - 1.463 & $<L O D-0.128$ & $<L O D$ & $<L O D$ & $<L O D$ & $<L O D$ & $<L O D$ & $<L O D$ & $<L O D$ & $<L O D$ \\
\hline No of positive samples & 0 & 0 & 0 & 0 & 0 & $5(26.32 \%)$ & $1(5.26 \%)$ & 0 & & $5(26.32 \%)$ & 0 & 0 & 0 & 0 & 0 \\
\hline \multirow[t]{2}{*}{ Type of rice (number of samples) } & \multicolumn{5}{|c|}{ Brown (2) } & \multicolumn{5}{|c|}{ Brown (2) } & \multicolumn{5}{|c|}{ Brown (19) } \\
\hline & $\mathrm{AFB}_{1}$ & $\mathrm{AFB}_{2}$ & $\mathrm{AFG}_{1}$ & $\mathrm{AFG}_{2}$ & AFT & $\mathrm{AFB}_{1}$ & $\mathrm{AFB}_{2}$ & & $\mathrm{AFG}_{2}$ & AFT & $\mathrm{AFB}_{1}$ & $\mathrm{AFB}_{2}$ & $\mathrm{AFG}_{1}$ & $\mathrm{AFG}_{2}$ & AFT \\
\hline mean (Lb) & $<\angle O D$ & $<\angle O D$ & $<L O D$ & $<\angle O D$ & $<L O D$ & $<L O D$ & $<L O D$ & $\angle L O D$ & $<L O D$ & $<\angle O D$ & 0.004 & $<L O D$ & $<L O D$ & $<\angle O D$ & 0.004 \\
\hline mean (Ub) & 0.008 & 0.006 & 0.006 & 0.002 & 0.02 & 0.008 & 0.00 & 0.006 & 0.002 & 0.02 & 0.011 & 0.006 & 0.006 & 0.002 & 0.023 \\
\hline Median & $<L O D$ & $<L O D$ & $<L O D$ & $<L O D$ & $<L O D$ & $<L O D$ & $<\angle O D$ & $<\angle O D$ & $<\angle O D$ & $<L O D$ & $<\angle O D$ & $<L O D$ & $<L O D$ & $<L O D$ & $<L O D$ \\
\hline Range & $<L O D$ & $<L O D$ & $\angle \angle O D$ & $<L O D$ & $<\angle O D$ & $<L O D$ & $<\angle O D$ & $<L O D$ & $\angle L O D$ & $<\angle O D$ & $<L O D-0.069$ & $<L O D$ & $<\angle O D$ & $<\angle O D$ & $<$ LOD -0.069 \\
\hline No of positive samples & 0 & 0 & 0 & 0 & 0 & 0 & 0 & 0 & 0 & 0 & $1(5.26 \%)$ & 0 & 0 & 0 & $1(5.26 \%)$ \\
\hline \multirow[t]{2}{*}{ Type of rice (number of samples) } & \multicolumn{5}{|c|}{ Parboiled (1) } & \multicolumn{5}{|c|}{ Parboiled (6) } & \multicolumn{5}{|c|}{ Parboiled (4) } \\
\hline & $\mathrm{AFB}_{1}$ & $\mathrm{AFB}_{2}$ & $\mathrm{AFG}_{1}$ & & AFT & $\mathrm{AFB}_{1}$ & $\mathrm{AFB}_{2}$ & $\mathrm{AFG}_{1}$ & $\mathrm{AFG}_{2}$ & AFT & $\mathrm{AFB}_{1}$ & $\mathrm{AFB}_{2}$ & $\mathrm{AFG}_{1}$ & $\mathrm{AFG}_{2}$ & AFT \\
\hline mean (Lb) & 0.102 & $<L O D$ & $<L O D$ & $\angle L O D$ & 0.102 & $<L O D$ & $<\angle O D$ & $<L O D$ & $<L O D$ & $<\angle O D$ & $<\angle O D$ & $<\angle O D$ & $<L O D$ & $<\angle O D$ & $<L O D$ \\
\hline mean (Ub) & 0.102 & 0.012 & 0.11 & 0.004 & 0.102 & 0.008 & 0.006 & 0.006 & 0.002 & 0.02 & 0.008 & 0.006 & 0.006 & 0.002 & 0.02 \\
\hline median & 0.051 & $<\angle O D$ & $<\angle O D$ & $<\angle O D$ & 0.051 & $<L O D$ & $<L O D$ & $<L O D$ & $<L O D$ & $<\angle O D$ & $<\angle O D$ & $<L O D$ & $<\angle O D$ & $<L O D$ & $<L O D$ \\
\hline Range & 0.102 & $<\angle O D$ & $<\angle O D$ & $<\angle O D$ & 0.102 & $<L O D$ & $<L O D$ & $<L O D$ & $<L O D$ & $<\angle O D$ & $<\angle O D$ & $<L O D$ & $<L O D$ & $<L O D$ & $<L O D$ \\
\hline No of positive samples & $1(100 \%)$ & 0 & 0 & 0 & $1(100 \%)$ & 0 & 0 & 0 & 0 & 0 & 0 & 0 & 0 & 0 & 0 \\
\hline \multirow[t]{2}{*}{ Type of rice (number of samples) } & \multicolumn{5}{|c|}{ Flake (1) } & \multicolumn{5}{|c|}{ Flake (2) } & & & & & \\
\hline & $\mathrm{AFB}_{1}$ & $\mathrm{AFB}_{2}$ & $\mathrm{AFG}_{1}$ & $\mathrm{AFG}_{2}$ & AFT & $\mathrm{AFB}_{1}$ & $\mathrm{AFB}_{2}$ & $\mathrm{AFG}_{1}$ & $\mathrm{AFG}_{2}$ & AFT & & & & & \\
\hline mean (Lb) & $<L O D$ & $<L O D$ & $<\angle O D$ & $<\angle O D$ & $<L O D$ & 0.108 & $<L O D$ & $<L O D$ & $<L O D$ & 0.108 & & & & & \\
\hline
\end{tabular}




\begin{tabular}{|c|c|c|c|c|c|c|c|c|c|c|c|c|c|c|c|}
\hline mean (Ub) & 0.008 & 0.006 & 0.006 & 0.002 & 0.02 & 0.058 & 0.006 & 0.006 & 0.002 & 0.118 & & & & & \\
\hline median & $<L O D$ & $<L O D$ & $<L O D$ & $<L O D$ & $<L O D$ & 0.108 & $<L O D$ & $<\angle O D$ & $<L O D$ & 0.108 & & & & & \\
\hline Range & $<L O D$ & $<L O D$ & $<L O D$ & $<L O D$ & $<L O D$ & $<$ LOD - 0.215 & $<L O D$ & $<L O D$ & $<L O D$ & $<L O D-0.215$ & & & & & \\
\hline No of positive samples & 0 & 0 & 0 & 0 & 0 & $1(50 \%)$ & 0 & 0 & 0 & $1(50 \%)$ & & & & & \\
\hline \multirow[t]{2}{*}{ Type of rice (number of samples) } & \multicolumn{5}{|c|}{ Red Rice (1) } & & & & & & \multicolumn{5}{|c|}{ Red Rice (10) } \\
\hline & $\mathrm{AFB}_{1}$ & $\mathrm{AFB}_{2}$ & $\mathrm{AFG}_{1}$ & $\mathrm{AFG}_{2}$ & AFT & & & & & & $\mathrm{AFB}_{1}$ & $\mathrm{AFB}_{2}$ & $\mathrm{AFG}_{1}$ & $\mathrm{AFG}_{2}$ & AFT \\
\hline mean (Lb) & $<L O D$ & $<\angle O D$ & $<L O D$ & $<L O D$ & $<L O D$ & & & & & & 8.440 & 1.078 & $<L O D$ & $<L O D$ & 9.428 \\
\hline mean $(U b)$ & 0.008 & 0.006 & 0.006 & 0.002 & 0.02 & & & & & & 8.446 & 1.093 & 0.006 & 0.002 & 9.444 \\
\hline median & $<L O D$ & $<L O D$ & $<L O D$ & $<L O D$ & $<L O D$ & & & & & & $<L O D$ & $<L O D$ & $<L O D$ & $<L O D$ & $<L O D$ \\
\hline Range & $<L O D$ & $\angle L O D$ & $<L O D$ & $<L O D$ & $<L O D$ & & & & & & $<$ LOD - 63.32 & $<L O D-8.591$ & $<L O D$ & $<L O D$ & $<$ LOD - 70.91 \\
\hline No of positive samples & 0 & 0 & 0 & 0 & 0 & & & & & & $2(20 \%)$ & $2(20 \%)$ & 0 & 0 & $2(20 \%)$ \\
\hline \multirow[t]{2}{*}{ Type of rice (number of samples) } & \multicolumn{5}{|c|}{ Brown w/ red (3) } & & & & & & \multicolumn{5}{|c|}{ Brown w/ red (3) } \\
\hline & $\mathrm{AFB}_{1}$ & $\mathrm{AFB}_{2}$ & $\mathrm{AFG}_{1}$ & $\mathrm{AFG}_{2}$ & AFT & & & & & & $\mathrm{AFB}_{1}$ & $\mathrm{AFB}_{2}$ & $\mathrm{AFG}_{1}$ & $\mathrm{AFG}_{2}$ & AFT \\
\hline mean (Lb) & 0.098 & $\angle L O D$ & $<L O D$ & $<L O D$ & 0.098 & & 1 & & & & 2.111 & 0.358 & $<L O D$ & $<L O D$ & 2.467 \\
\hline mean $(U b)$ & 0.100 & 0.006 & 0.006 & 0.002 & 0.101 & & & & & & 2.114 & 0.360 & 0.006 & 0.002 & 2.473 \\
\hline median & $<L O D$ & $\angle L O D$ & $<L O D$ & $<L O D$ & & & & & & & 2.243 & 0.23 & $<L O D$ & $<L O D$ & 2.47 \\
\hline Range & $<L O D-0.283$ & $<L O D$ & $<L O D$ & $<$ LOD & -OD -0.28 & & & & & & $<$ LOD - 4.09 & $<L O D-0.845$ & $<L O D$ & $<L O D$ & $<$ LOD - 4.93 \\
\hline No of positive samples & $1(33.3 \%)$ & 0 & 0 & & $1(33.3 \%)$ & & & & & & $2(66.67 \%)$ & $2(66.67 \%)$ & 0 & 0 & $2(66.67 \%)$ \\
\hline \multirow[t]{2}{*}{ Type of rice (number of samples) } & & & & & & & & & & & \multicolumn{5}{|c|}{ Black Rice (8) } \\
\hline & & & & & & & & & & & $\mathrm{AFB}_{1}$ & $\mathrm{AFB}_{2}$ & $\mathrm{AFG}_{1}$ & $\mathrm{AFG}_{2}$ & AFT \\
\hline mean (Lb) & & & & & & & & & & & 0.011 & $<L O D$ & 0.047 & $<L O D$ & 0.059 \\
\hline mean $(U b)$ & & & & & & & & & & & 0.018 & 0.006 & 0.050 & 0.002 & 0.069 \\
\hline median & $v$ & & & & & & & & & & $<L O D$ & $<L O D$ & 0.067 & $<L O D$ & 0.067 \\
\hline Range & & & & & & & & & & & $<$ LOD - 0.09 & $<L O D$ & $<$ LOD - 0.133 & $<L O D$ & $<L O D-0.133$ \\
\hline No of positive samples & & & & & & & & & & & $1(12.5 \%)$ & 0 & $4(50 \%)$ & 0 & $4(50 \%)$ \\
\hline
\end{tabular}

LOD: Limit of detection. 
Highlights

- The first report of $A$. novoparasiticus, $A$. arachidicola and A. pseudocaelatus in rice and rice plantation soil.

- $17 \%$ of the $A$. flavus isolates from rice were aflatoxin type B producers.

- Less than $14 \%$ of the rice samples were contaminated with aflatoxins. 